\title{
ODOS TEMPERATŪROS VIRŠ DIRBANČIO RAUMENS KITIMO DËSNINGUMAI
}

\author{
Povilas Algimantas Sirvydas¹, Albertas Skurvydas, Jūratė Nadzeikienė, Saulè Sipavičienė،
} Lietuvos žemès ükio universitetas ${ }^{1}$, Lietuvos kūno kultūros akademija, Kaunas, Lietuva

\begin{abstract}
Povilas Algimantas Sirvydas. Profesorius biomedicinos mokslų daktaras, technologijos mokslų habilituotas daktaras. Lietuvos žemės ūkio universiteto Šilumos ir biotechnologijų inžinerijos katedros profesorius. Mokslinių tyrimų kryptis — bioenergetika.
\end{abstract}

\section{SANTRAUKA}

Visos energijos rūšys, tarp ju biologinè ir mechaninè, galiausiai virsta šiluma. Fizinio krūvio metu šiluma išsiskiria žmogaus organizme, veikdama energijos balansq, ir pasireiškia lokaliu temperatūros padidèjimu. Lokalus temperatūros padidejimas dirbančiuose raumenyse paklüsta termodinamikos dèsniams.

Straipsnyje analizuojami odos virš dirbančio raumens temperatūros kitimo désningumai. Pagal raumens šilumos balansa nustatyta, kaip odos temperatūros kitimas priklauso nuо tarpusavyje susijusiu vidiniu ir išoriniu veiksniu. sudaryta odos temperatūros pokyčio diferencinè lygtis. Atlikti odos temperatūros virš dirbančio raumens matavimai visiškai patvirtino teorinę prielaida, kad dirbantis raumuo patiria išilimo, nusistovéjusios temperatūros ir aušimo periodus. Odos lokalios temperatūros virš dirbančio raumens ir šios temperatüros pokyčiu tyrimai gali büti panaudoti sportininko parengtumui ̌vertinti ir norint išsiaiškinti, ar sportininkui (dirbančiajam) tinka aprangos konstrukcija.

Raktažodžiai: šilumos balansas, lokali temperatūra, raumuo.

\section{IVADAS}

$\check{Z}$ mogus, kaip ir bet kuris gyvasis organizmas, yra atvira sistema, vykdanti medžiagų ir energijos apykaitą su aplinka. Žmogus iš aplinkos maisto, šilumos ir kitais pavidalais gauna tam tikrą energijos kieki, reikalinga darbui atlikti, gyvybiniams procesams palaikyti. Bet kurios veiklos metu žmogaus organizme atliekamas trijų rūšių darbas (Bennett, 1984; Woledge, 1998; Febbraio, 2001; Иванов, 1990). Ergonominių klausimų sprendimui lemiamos reikšmès turi fiziologinio darbo rūšis, tiesiogiai susijusi su žmogaus veiklos aktyvumu, jo atliekamu mechaniniu darbu. Tik maža dalis žmogaus gaunamos energijos sueikvojama mechaniniam darbui atlikti.
Energija, nesunaudota mechaniniam darbui atlikti, virsta šiluma, kuri kaupiasi organizme didindama temperatūrą, arba ji atiduodama į aplinką kaip metabolitas. Kuo mažesnis mechaninio darbo naudingumo koeficientas, tuo daugiau išskiriama šilumos tam pačiam mechaniniam darbui atlikti. Daugelyje tyrimų minimas žmogaus mechaninio darbo naudingumo koeficientas $\eta$ neviršija 10 $25 \%$ ribų priklausomai nuo dirbančių raumenų masès ir darbo pobūdžio (Fanger, 1970; Čyras ir kt., 2003; Адамчук, 1999).

Yra žinoma, kad žmogaus išskiriamas šilumos kiekis ir jo pokytis, pasikeitus fizinès veiklos rūšiai ar išorinès aplinkos sąlygoms, tiesiogiai paro- 
do žmogaus terminę būseną (Fanger, 1970; Patterson et al., 1998; Becker, 2003; Holmer, 2004). Normalų žmogaus organizmo funkcionavimą garantuoja stabili terminè būsena. Ši terminè būsena ivardijama kaip šiluminis komfortas, lemiantis žmogaus darbingumą, gerą savijautą ir sveikatą. Priklausomai nuo žmogaus energijos sąnaudu ramybès ir fizinio darbo metu skirtumo kinta žmogaus organizme susidarantis šilumos kiekis, kurį reikia pašalinti, kad organizmas neperkaistų, išliktų stabilios terminès būsenos.

Fizinio darbo pobūdis lemia skirtingu raumenų grupių darbą ir nevienodą išsiskiriančios šilumos kiekị dirbančiuose raumenyse. Didejjant dirbančio raumens temperatūrai, kartu didèja ir lokali odos temperatūra virš dirbančio raumens. Lokali odos paviršiaus temperatūra parodo ne tik vykstančiu procesų (net ir patologinių) intensyvumą giluminiuose audiniuose, bet ir fizinès apkrovos itaką, sprendžiant ergonominius klausimus (Gagge et al., 1968; Binkhorst et al., 1977; Mohr et al., 2004; Кандрор, 1984).

Straipsnyje nagrinèjami temperatūros virš dirbančio raumens kitimo dèsningumai raumens ¡̇̌silimo, pastovios temperatūros ir aušimo metu. Pateikiama lokalią temperatūrą formuojančiuc veiksnių analizè ir fizinio krūvio įtaka lokaliai žmogaus kūno paviršiaus temperatūrai bei organizmo išskiriamam šilumos kiekiui.

Tyrimo tikslas - atlikti odos virš dirbančio raumens temperatūros tyrimus, norint nustatyti jos kitimo dèsningumus ir lokalios temperatūros pokyčiu priklausomybę nuo fizinès apkrovos.

\section{TYRIMO METODIKA}

Buvo tiriami suaugę (20-23 metų) aktyviai nesportuojantys vyrai $(\mathrm{n}=10)$.

Lokali odos paviršiaus temperatūra matuota individualios gamybos $\mathrm{Cu}-\mathrm{CuNi}$ termoelementais. Netinkamai pritvirtinus temperatūros jutikli ar neivertinus biologiniu ir fizikinių matuojamos aplinkos savybiu, gali atsirasti nesisteminiu paklaidú. Jos galimos dèl to, kad temperatūra, kurią rodo jutiklis, yra šilumos mainų visumos su matuojamu objektu ir aplinka rezultatas. Norint išvengti nesisteminiu temperatūros matavimo paklaidų, visi temperatūros jutikliai turi būti paklojami ir tvirtinami vienodai pagal izotermą 100 jutiklio skersmenu ilgiu. Vykdant šį reikalavimą, standartinių termoelementų dèl jų didelių matmenų panaudoti negalèjome. Todèl gaminome termoelementus iš $\mathrm{Cu}-\mathrm{CuNi}$ laidų, kurių skersmuo $0,07 \mathrm{~mm}$. Noredami išvengti aplinkos poveikio, juos tvirtinome odos paviršiuje $5 \times 7 \mathrm{~mm}$ pleistro gabalèliais. Taip įvykdème fiziologinių ir mikroklimatinių tyrimų reikalavimus, kurie keliami matuojant temperatūrą (ISO 7730, 1994; Huizenga et al., 2001; Кандрор, 1984; Преображенский, 1978; Сирвидас, Юшка, 1973). Po termoelementų taravimo laboratorinemis sąlygomis ivertinome temperatūros matavimo metodiką ir nustateme, kad termoelementu priklijavimas prie paviršiaus 100 jutiklio skersmenų ilgio pleistro gabalèliu garantuoja $\pm 0,021^{\circ} \mathrm{C}$ matuojamos temperatūros neapibrèžties ribas, kai matavimų pasikliovimo tikimybė $P=99 \%$. Atliekant odos paviršiaus temperatūros lyginamają analizę, visiškai tenkina $\pm 0,1^{\circ} \mathrm{C}$ tikslumas. Taigi galima teigti, kad mūsų naudojama temperatūros matavimo metodika keliamus reikalavimus patenkina.

Lokali kūno paviršiaus temperatūra buvo matuojama virš dirbančio raumens. Tyrimui pasirinktas keturgalvis šlaunies raumuo. Zona virš dirbančio raumens buvo atvira, t. y. be izoliacinio sluoksnio. Tuo siekiama gauti kuo tikslesnius žmogaus kūno paviršiaus temperatūrinius pokyčius (keičiantis fizinei apkrovai), kurių neiškraipytų termoizoliacinès drabužiu savybès, turinčios lemiamos įtakos žmogaus šilumos su aplinka mainams. Visų tyrimų metu temperatūra virš šlaunies keturgalvio raumens buvo registruojama ramybès, raumens darbo ir poilsio metu septyniuose taškuose. Temperatūros matavimo taškų išdèstymo virš raumens schema pateikta 1 paveiksle.

Lokali temperatūra buvo tiriama esant trijų rūšių apkrovoms:

1) trumpalaikio (1 $\mathrm{min}) 4 \mathrm{~kg}$ svorio kilnojimo modeliuojant lengvą darbą.

2) $2 \mathrm{~kg}$ svorio kilnojimo $4 \mathrm{~min}$ - modeliuojant lengvą darbą.

3) minant veloergometrą $20 \mathrm{~min}$ - modeliuojant vidutinio sunkumo darbą.

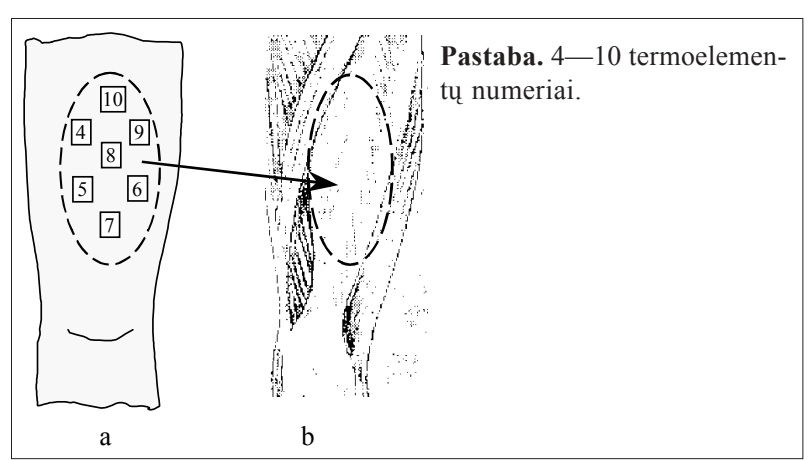

1 pav. Termoelementų išdèstymo schema ant kairiosios šlaunies virš dirbančio raumens (a) ir keturgalvio raumens vaizdas (b) 
Pirmo tyrimo metu raumens darbui modeliuoti pasirinkta trumpalaike $4 \mathrm{~kg}$ apkrova, kurios metu atliktas 1 min mechaninis darbas $A$. Žmogus sèdèdamas koja svorị kilnojo $40 \mathrm{~min}^{-1}$ dažnumu i $0,5 \mathrm{~m}$ aukšti. Apskaičiavus darbo galią $L$, nustatytos žmogaus energijos sąnaudos $M$, kai svorio kèlimo naudingumo koeficientas $\eta=0,09$.

Antro tyrimo metu raumens darbas buvo modeliuojamas $2 \mathrm{~kg}$ apkrova. Žmogus sèdèdamas svorị kilnojo 4 minutes tuo pačiu $40 \mathrm{~min}^{-1}$ dažnumu i $0,5 \mathrm{~m}$ aukšti.

Tyrimo veloergometru apkrova buvo $100 \mathrm{~W}$, apsisukimu dažnis $-50 \mathrm{~min}^{-1}$, darbo trukmé $20 \mathrm{~min}$.

\section{REZULTATAI}

Odos temperatūros kitimo virš dirbančio raumens teorinès paieškos. Jei dirbančiame raumenyje išskirsime atskirą elementą, galime teigti, kad apskritai pagrindiniai šilumos šaltiniai yra kraujotakos sistema, gretimi organai ir darbo metu raumenyje išsiskirianti šiluma (2 pav.).

Kaip matyti dirbančio raumens šilumos mainu schemoje (2 pav.), dali gaunamos šilumos raumuo akumuliuoja, o perteklinè šiluma pašalinama kraujotakos sistemos ir raumens audinių šilumos laidumu i gretimus audinius, turinčius žemesnę temperatūrą nei dirbantis raumuo. Medicininejje literatūroje teigiama, kad konvekcinis šilumos transportavimo (kraujotakos) būdas yra pagrindinis, nes šilumos laidumas per audinius yra nedidelis (Байер, 1962; Кощеев, 1981). Čia pastebimas prieštaravimas, nes iš literatūroje (Кощеев, 1981; Золина, 1983) pateikiamų duomenų — kraujotakos ir kvėpavimo sistemose susidarantis šilumos kiekis ramybès ir darbo metu iš esmès nesikeičia. Vadinasi, šiluma i gretimus audinius perduodama laidumu. Mes nesiimame bendro šilumos atidavimo ị aplinką proceso kiekybinio konvekcijos ir

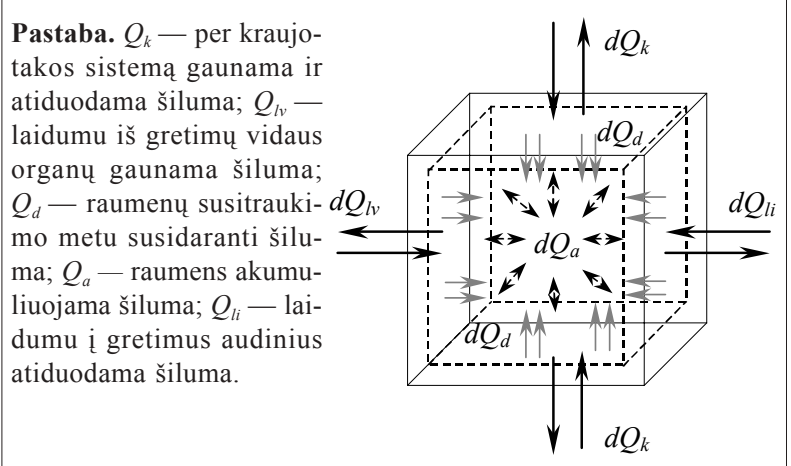

2 pav. Dirbančio raumens elementaraus tūrio šilumos mainų schema laidumo būdu įvertinimo, tik norime nustatyti žmogaus kūno paviršiaus lokalios temperatūros pokyčius, kuriuos lemia dirbančio raumens šilumos atidavimas laidumu, ir su lokalios temperatūros pokyčiais susijusius žmogaus šilumos mainus su aplinka.

Remdamiesi šilumos mainų schema (2 pav.), galime užrašyti dirbančio raumens šilumos balanso lygti apibendrintai:

$$
Q_{d} \pm Q_{k} \pm Q_{l v}=Q_{a} \pm Q_{l i}
$$

Kiekvienas (1) lygties narys yra kintantis ir priklausomas nuo kitų šilumos balanso narių, nuo žmogaus veiklos rūšies ir raumeniui tenkančios fizinès apkrovos dydžio, todèl (1) lygtị tikslinga analizuoti perrašius ją diferencialine forma:

$$
d Q_{d} \pm d Q_{k} \pm d Q_{l v}=d Q_{a} \pm d Q_{l i}
$$

Kaip matyti iš (2) lygties, žmogui keičiant veiklos rūši pakinta ir išsiskiriantis šilumos kiekis. Žmogui atliekant fizinį darbą ir padidejjus raumenų apkrovai, dèl intensyvių raumenų susitraukimų išsiskiria papildomas šilumos kiekis $d Q_{d}$. Dèl to suaktyvėja termoreguliacinio mechanizmo veikla ir kraujotakos sistema nutekantis šilumos kiekis pakinta dydžiu $d Q_{k}$. Dirbančiame organizme papildomas šilumos kiekis susidaro ir vadinamame žmogaus branduolyje (vidaus organuose), kuris laidumu suteikia raumenims šilumos kieki $d Q_{l v}$. Pastarasis pokytis nèra didelis ir neturetuc lemti šilumos mainų su aplinka. Kaip minèta, dalị šilumos raumuo akumuliuoja $d Q_{a}$, dideja jo temperatūra. Žmogaus termoreguliacinio mechanizmo galimybès ribotos, todèl dalis šilumos $d Q_{l i}$ iš raumens yra pašalinama laidumu i gretimus audinius, turinčius mažesnę temperatūrą negu dirbantis raumuo.

Per kraujotakos sistemą ramybès metu gaunamas, o darbo metu nutekantis šilumos kiekis $d Q_{k}$ priklauso nuo individualiu žmogaus kraujotakos sistemos ypatumų ir fizinès apkrovos dydžio, kuris lemia laidumu gaunamos raumens šilumos pokyti $d Q_{v^{*}}$. Vis dèlto fiziné apkrova (arba žmogaus atliekamo darbo sunkumas) lemia raumenyje darbo metu išsiskiriančios šilumos pokytị $d Q_{d}$. Lygties (2) kaireje esančius narius, kurie neatsiejamai priklauso vienas nuo kito ir veikia kaip vieninga sistema, galima apibendrintai pavadinti fiziologinio darbo ir termoreguliacijos šilumos kiekiu, susidarančiu raumens tūrio elemente $d V$ per laiko intervalą $d \tau$, ir išreikšti lygtimi:

$$
d Q_{d} \pm d Q_{k} \pm d Q_{l v}=q_{v} d V d \tau
$$


čia $q_{v}$ - fiziologinio darbo ir termoreguliacijos šilumos srauto tankis $\left(\mathrm{W} / \mathrm{m}^{2}\right)$, priklausantis nuo žmogaus energijos $E$ nagrinèjamos veiklos sąnaudu, $q_{v}=f(E)$.

Kaip matyti iš lygties (3), narys $q_{v}$ tiesiogiai priklauso nuo žmogaus atliekamo darbo sunkumo, jo metu organizmui reikalingos energijos sąnaudu ir fizinio darbo metu atsirandančių fiziologinių termoreguliacijos mechanizmo ypatumų. Ramybès metu narys $q_{v}$ yra mažesnis dydžiu $d Q_{d}$.

Raumens akumuliuojama šiluma $d Q_{a}$ yra sunaudojama raumens vidinei energijai didinti. Ši šiluma gali būti išreikšta lygtimi:

$$
d Q_{a}=c_{r} \rho_{r} \frac{\partial t_{r}}{\partial \tau} d V d \tau
$$

čia: $t_{r}$ - raumens temperatūra, ${ }^{\circ} \mathrm{C}$;

$c_{r}$ - raumens savitoji masès šiluma, $\mathrm{J} /(\mathrm{kg} \cdot \mathrm{K})$;

$\rho_{r}$ - raumens tankis, $\mathrm{kg} / \mathrm{m}^{3}$.

Iš raumens tūrio elemento $d V$ laidumu perduodamas šilumos kiekis gali būti išreiškiamas tokia lygtimi:

$$
d Q_{l i}=-\lambda_{r}\left(\frac{\partial^{2} t_{r}}{\partial x^{2}}+\frac{\partial^{2} t_{r}}{\partial y^{2}}+\frac{\partial^{2} t_{r}}{\partial z^{2}}\right) d V d \tau,
$$

čia $\lambda_{r}$ - raumens šilumos laidumo koeficientas, $\mathrm{W} /(\mathrm{m} \cdot \mathrm{K})$;

$$
\frac{\partial^{2} t_{r}}{\partial x^{2}}, \frac{\partial^{2} t_{r}}{\partial y^{2}}, \frac{\partial^{2} t_{r}}{\partial z^{2}} \text { - raumens temperatūros }
$$

kitimo pagreičiai $x, y, z$ kryptimis tūrio elemente $d V$.

I (2) lygti irašydami (3), (4) ir (5) išraiškas, gauname fiziologinio darbo ir termoreguliacijos šilumos srauto tankio išraišką:

$$
q_{v}=c_{r} \rho_{r} \frac{\partial t_{r}}{\partial \tau}-\lambda_{r}\left(\frac{\partial^{2} t_{r}}{\partial x^{2}}+\frac{\partial^{2} t_{r}}{\partial y^{2}}+\frac{\partial^{2} t_{r}}{\partial z^{2}}\right)=c_{r} \rho_{r} \frac{\partial t_{r}}{\partial \tau} \pm \lambda_{r} \nabla^{2} t
$$

čia: $\nabla^{2} t_{r}$ - Laplaso operatorius.

Remdamiesi lygtimi (6) galime įvertinti, kaip per tam tikrą laikotarpi kinta raumens temperatūra:

$$
\frac{\partial t_{r}}{\partial \tau}= \pm \frac{\lambda_{r}}{c_{r} \rho_{r}}\left(\frac{\partial^{2} t_{r}}{\partial x^{2}}+\frac{\partial^{2} t_{r}}{\partial y^{2}}+\frac{\partial^{2} t_{r}}{\partial z^{2}}\right)+\frac{1}{c_{r} \rho_{r}} q_{v}
$$

Šilumos nutekejjimui iš dirbančio raumens i aplinką itakos turi riebalinio audinio, dermos ir epidermio šilumos laidumo koeficientai (atitinkamai $\lambda_{r b}, \lambda_{d}, \lambda_{e}$ ), kiekvieno šių sluoksnių savitosios masiu šilumos $c_{r b}, c_{d}, c_{e}$ ir tankiai $\rho_{r b}, \rho_{d}, \rho_{e}$. Taip pat itakos turi fizinio darbo metu išgarinama šiluma, priklausanti nuo išgarinamo prakaito masès kiekio $m_{p r}$ ir entalpijos $i$, žmogaus odos paviršiaus suminis šilumos atidavimo koeficientas $\alpha$ ir aplinkos temperatūra $t_{a p l}$. Ivertinę paminètus parametrus, lygti (6) galime papildyti ir užrašyti šitaip:

$$
\begin{aligned}
& q_{v}=c_{r} \rho_{r} \frac{\partial t_{r}}{\partial \tau}+c_{r b} \rho_{r b} \frac{\partial t_{r b}}{\partial \tau}+c_{d} \rho_{d} \frac{\partial t_{d}}{\partial \tau}+c_{e} \rho_{e} \frac{\partial t_{e}}{\partial \tau}-\lambda_{r} \nabla^{2} t_{r}- \\
& -\lambda_{r b} \nabla^{2} t_{r b}-\lambda_{d} \nabla^{2} t_{d}-\lambda_{e} \nabla^{2} t_{e}+m_{p r} \frac{d i}{d \tau}+\alpha \frac{d t_{a p l}}{d \tau}
\end{aligned}
$$

Lygtis (8) ivvertina, kaip per tam tikrą laikotarpi kinta temperatūra žmogaus kūno paviršiuje, t. y. $t_{e}$. Iš (9) lygties epidermio (arba žmogaus kūno paviršiaus) temperatūros pokytis per laiką išreiškiamas lygtimi:

$\frac{\partial t_{e}}{\partial \tau}=\frac{1}{c_{e} \rho_{e}}\left[\sum_{j=1}^{n} \lambda_{j} \nabla^{2} t_{j}+q_{v}-\sum_{j=1}^{n-1} c_{j} \rho_{j} \frac{\partial t_{j}}{\partial \tau}-m_{p r} \frac{d i}{d \tau}-\alpha \frac{d t_{a p l}}{d \tau}\right]$ (9)

Kaip matyti iš (9) lygties, žmogaus kūno paviršiaus temperatūrą lemia daugelis tarpusavyje susijusių vidinių ir išorinių veiksnių. Teorinis šios temperatūros apskaičiavimas yra galimas, tačiau komplikuotas dèl to, kad neišspręsta žmogaus fiziologinių veiksnių tarpusavio ryšių problema ir trūksta žinių apie atskiras žmogaus kūno audinių fizikinių dydžių konstantas. Lokalios temperatūros pokyčiai, žmogui pereinant iš ramybès ị darbinę būseną ir atliekant tam tikro sunkumo darbą, gali būti tiriami eksperimentiškai.

Odos temperatūros kitimo virš dirbančio raumens eksperimentiniai duomenys. Odos temperatūros kitimas virš dirbančio raumens, kilnojant $2 \mathrm{~kg}$ svori 4 minutes tuo pačiu $40 \mathrm{~min}^{-1}$ dažnumu i $0,5 \mathrm{~m}$ aukští, pateiktas 3 paveiksle. Akivaizdūs odos temperatūros pokyčiai po $1 \mathrm{mi}-$ nutès darbo.

Pastebimas skirtingas temperatūros kitimo pobūdis virš dirbančio raumens. Vidinejje raumens puseje visais stebetais atvejais antrą minutę nuo krūvio pradžios pastebimas nedidelis (iki $0,16^{\circ} \mathrm{C}$ ) temperatūros sumažejimas, po kurio seka staigesnis temperatūros augimas. Temperatūra, esant minètai apkrovai, pakyla $\left(0,9-1,6^{\circ} \mathrm{C}\right)$ ir pasiekia sąlygiškai stabilią šilumos mainų būseną po 4 darbo minučių. Nutraukus darbą, pastovi temperatūra sąlygiškai laikosi dar $10 \mathrm{~min}$.

Analogiškas temperatūros kitimas pastebimas kilnojant $4 \mathrm{~kg}$ svori 1 minutę $40 \mathrm{~min}^{-1}$ dažnumu i $0,5 \mathrm{~m}$ aukšti (4 pav.).

Lyginant duomenis, pateiktus 3 ir 4 paveiksle, matyti, kad raumeniui dirbant visiškai skirtingais krūviais, odos temperatūros kitimo dèsningumas virš dirbančio raumens išlieka analogiškas. Tem- 


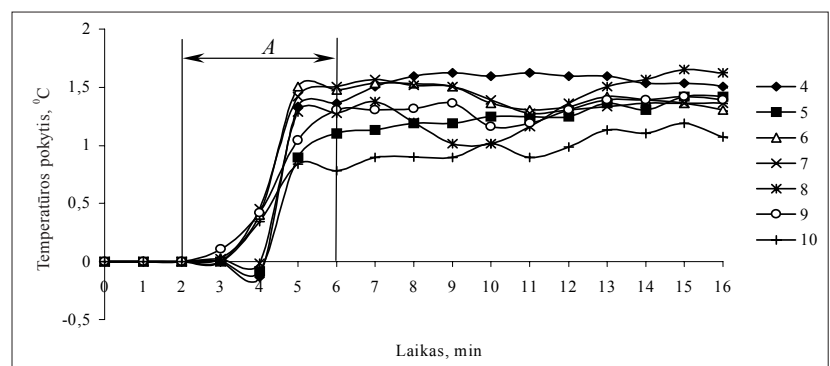

Pastaba. Matavimo taškų išdėstymas pateiktas 1 pav. $A$ - raumens darbo periodas.

3 pav. Odos temperatūros kitimas virš dirbančio raumens 2 kg (4 min) apkrovos metu

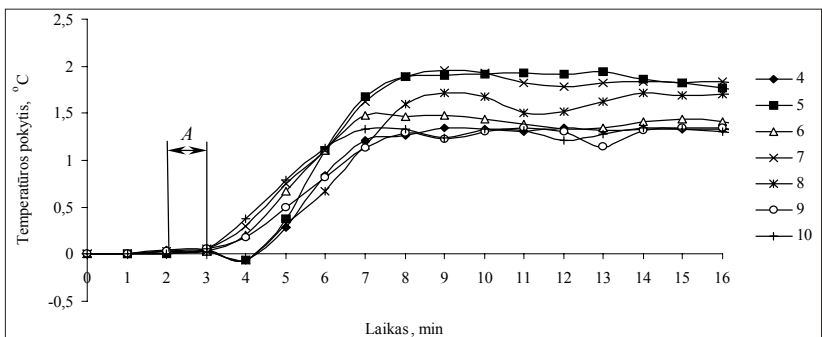

Pastaba. Matavimo taškų išdėstymas pateiktas 1 pav. $A$ - raumens darbo periodas.

4 pav. Odos temperatūros kitimas virš dirbančio raumens 4 kg (1 min) apkrovos metu

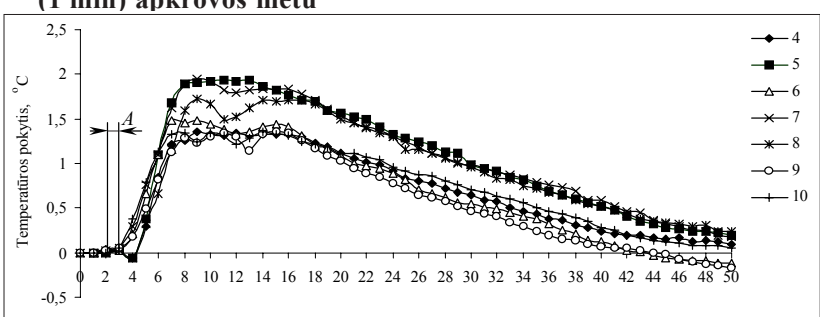

Pastaba. Matavimo taškų išdėstymas pateiktas 1 pav. $A$ - raumens darbo periodas.

5 pav. Odos temperatūros kitimas virš dirbančio raumens 4 kg (1 min) apkrovos metu

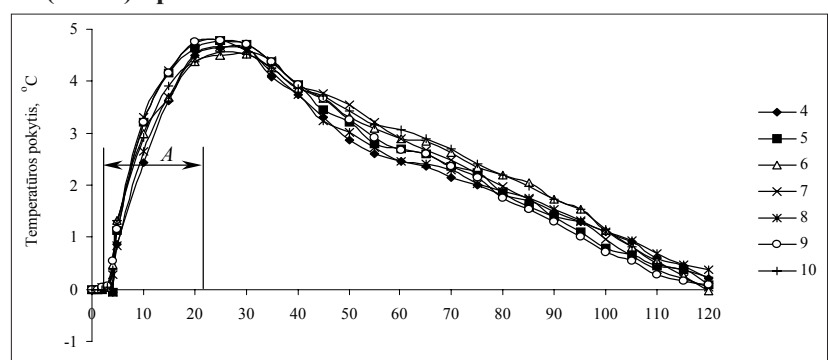

Pastaba. Matavimo taškų išdėstymas pateiktas 1 pav. $A$ - raumens darbo periodas $(20 \mathrm{~min})$.

6 pav. Odos temperatūros kitimas virš dirbančio raumens esant $100 \mathrm{~W}$ apkrovai veloergometru

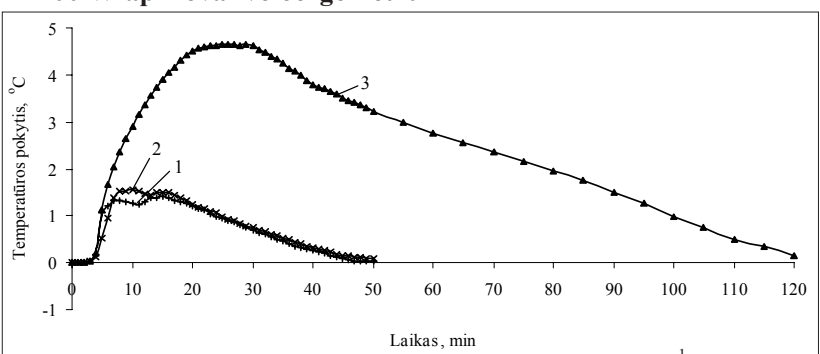

Pastaba. $1-2 \mathrm{~kg}$ svorio kilnojimas 4 minutes $40 \mathrm{~min}^{-1}$ dažnumu; 2 -4 kg svorio kilnojimas 1 minutę $40 \mathrm{~min}^{-1}$ dažnumu; 3-100 W 20 min apkrova veloergometru.

7 pav. Vidutinės odos temperatūros kitimo virš dirbančio raumens priklausomybė nuo apkrovos peratūra kyla léčiau (4 pav.) dèl trumpo apkrovimo periodo, kuris nutraukiamas po $1 \mathrm{~min}$ pastebejjus pirmuosius temperatūros pokyčius odos paviršiuje virš dirbančio raumens. Pasibaigus sąlygiškai nusistovèjusios temperatūros periodui, prasideda temperatūros kritimo periodas ( 5 pav.).

Trumpalaikès $4 \mathrm{~kg} 1 \mathrm{~min}$ apkrovos metu odos temperatūra kyla nedaug (5 pav.). Baigus darbą, temperatūra per 4 min padidèja iki $1,25-2^{\circ} \mathrm{C}$ ir išlieka sąlygiškai pastovi 8-16 min. Šiuo laiko intervalu kai kuriuose matavimo taškuose pastebimas nedidelis temperatūros kritimas (apie $0,2^{\circ} \mathrm{C}$ ). Raumens aušimas ir temperatūros kritimas iki pradinès reikšmès trunka $30-34 \mathrm{~min}$.

Tyrimo veloergometru metu buvo atliekamas ilgalaikis vidutinio sunkumo darbas. Kaip matyti 6 paveiksle, pradiniu apkrovos momentu temperatūra išlieka artima ramybès būsenos temperatūrai. Per penkių minučių darbo laikotarpi pastebimas staigus temperatūros padidejimas iki $1,3^{\circ} \mathrm{C}, 5-$ 10 min temperatūros pokytis siekia $2,5-3,3^{\circ} \mathrm{C}$, $15-20 \mathrm{~min}$ - temperatūra pakyla iki $4,4-4,8^{\circ} \mathrm{C}$, o baigus darbą apie 10 min išlieka stabili. Pradinè ramybès būsenos temperatūra nusistovi per 90 min nutraukus darbą.

Lyginant tarpusavyje visų trijų apkrovų metu gautus vidutinius temperatūros kitimo dėsningumus ir temperatūros pokyčius (6 pav.) matyti, kad jie tiesiogiai susiję su apkrovos dydžiu. Aptartų tyrimų metu raumens išilimo temperatūros kitimo kreiviu kilimo kampas yra vienodas, trumpalaikès apkrovos metu temperatūros kilimas daugiau inertiškas, nes po minutès pertraukos raumuo jau nebedirba. Raumens aušimo procesas visų trijų apkrovų metu yra vienodo pobūdžio. Tai rodo savo dydžiu artimi kreivių nusileidimo kampai (7 pav.).

\section{REZULTATŲ APTARIMAS}

Raumens temperatūros kitimo dèsningumai. Ramybès būsenoje organizmas atlieka tik fiziologini darbą, būtiną gyvybinèms funkcijoms palaikyti. Visa gaunama ir fiziologiniam darbui išeikvota energija paverčiama šiluma, kurios dalis pašalinama į aplinką per kūno išorinius paviršius. Esant ramybès būsenai, žmogaus odos lokali temperatūra yra pastovi.

Fizinio darbo metu i bendrą organizmo veiklą isitraukia atskiros raumenu grupes. Priklausomai nuo fizinès veiklos pobūdžio tam tikros raumenu grupès gauna apkrovą, susitraukinèja griaučiu raumenys, išsiskiria šiluma. Raumens išilimą ir 
šilumos atidavimą iš raumens ị aplinką rodo palaipsniui kylanti, paskui pastovi žmogaus kūno paviršiaus temperatūra. Tikètinas temperatūros kitimo pobūdis virš dirbančio raumens pavaizduotas 8 paveiksle.

Esant ramybès būsenai ( $\tau_{1}$ periodas), raumens termine pusiausvyra yra nusistovejusi, t. y. išskiriamas šilumos kiekis ir temperatūra $\left(Q_{r}=\right.$ const, $t_{r}=$ const $)$ nekinta. Žmogui pradejus dirbti $\left(\tau_{2}\right.$ periodas) raumens terminè pusiausvyra pažeidžiama, išsiskiria papildomas šilumos kiekis. Dirbant toliau yra išnaudojamos termoreguliacinio mechanizmo galimybès, vyksta tolimesnis raumens išilimo procesas, kurio sparta proporcinga fizinio krūvio dydžiui (1, 2 kreivès, 8 pav.). Raumens temperatūros kitimo greiti $d t / d \tau$ lemia žmogaus fizinès veiklos krūvis. Pasiekus tam tikrą ribą ( $\tau_{3}$ periodas), nusistovi raumens šiluminè pusiausvyra, lemianti pastovią dirbančio raumens temperatūrą $t_{\text {maks. }}\left(d t_{r} / d \tau=0\right)$. Baigus darbą $\left(\tau_{4}\right.$ periodas), prasideda raumens atsigavimo procesas, kuri lydi temperatūros kritimas raumenyje. Temperatūrų skirtumas $t_{\text {maks }}-t_{r}$ leidžia įvertinti šilumos išsiskyrimo padidejimą fizinio darbo metu.

Netiesioginis organizmo šilumos produkcijos ir išskyrimo į aplinką kiekybinio îvertinimo matas yra lokali žmogaus kūno paviršiaus temperatūra. Jos dydị lemia vidiniai ir išoriniai šilumos apykaitos procesai, vykstantys žmogaus organizme. Vidinių šilumos mainų atveju žmogaus „branduolyje“ susidariusi šiluma kraujotakos ir audinių laidumu atiduodama žmogaus, ,apvalkalui“. Toliau vyksta šilumos mainai tarp žmogaus kūno paviršiaus ir aplinkos. Fizinis krūvis pagreitina šilumos susidarymą raumenyse, kuris tiesiogiai veikia žmogaus kūno paviršiaus temperatūrą virš dirbančio raumens. Dirbančio raumens šilumos mainų mechanizmo analizė leidžia aprašyti vykstančių procesų priklausomybę.

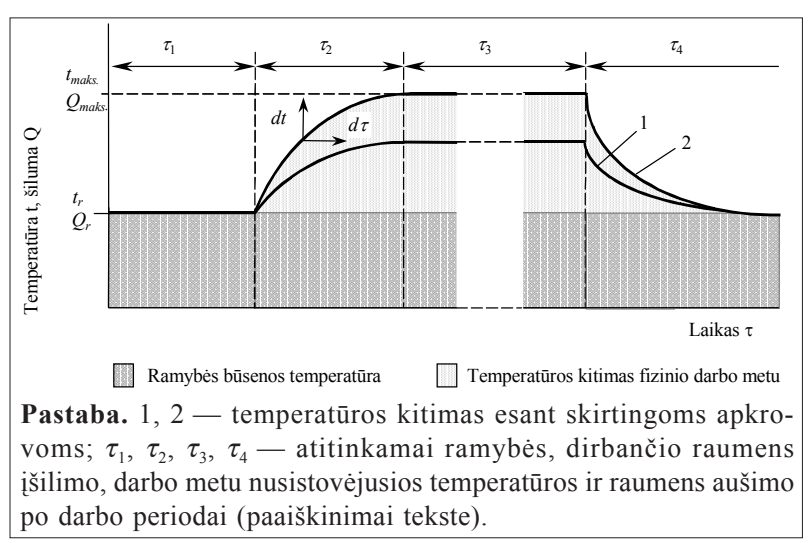

8 pav. Lokalios temperatūros virš dirbančio raumens kitimo schema
Odos temperatūros kitimo virš dirbančio raumens aptarimas. Esant ramybès būsenai, temperatūra virš stebimo raumens nevienoda, tačiau stabili. Tiriamo raumens atskiri audiniai nevienodai kontaktuoja su kitais audiniais (aplinkiniais raumenimis, oda ir kt.), todèl atskiruose dirbančio raumens audiniuose susidaro nevienodos šilumos mainų sąlygos. Tai lemia skirtingą lokalią temperatūrą pačiame raumenyje, kartu ir nevienodą lokalią temperatūrą virš dirbančio raumens. Todèl šio tyrimo duomenys pateikiami ne absoliučiais dydžiais, bet lyginant temperatūros pokytị su ramybès būsenos temperatūra. Tačiau įdomu tai, kad skirtinguose matavimo taškuose gauti temperatūros kitimo rezultatai tarpusavyje koreliuoja. Jų koreliacijos koeficientai yra $0,94-0,97$. Tai rodo stiprų matavimo rezultatų tarpusavio koreliacini ryšį ir patvirtina, kad šilumos perdavimo per audinius procesai vyksta pagal tuos pačius dèsningumus nepriklausomai nuo temperatūros matavimo taško virš raumens.

Raumeniui pradejjus dirbti, išsiskiria šiluma, didèja jo temperatūra. Visais atvejais pastebimas pavèluotas temperatūros kitimas odos paviršiuje virš dirbančio raumens. Odos temperatūros kitimo inertiškumą paaiškina šilumos plitimo dèsningumai ir audinių virš dirbančio raumens termoizoliacinès savybès.

\section{IŠVADOS}

1. Odos temperatūros virš dirbančio raumens teoriškai modeliuoti negalime dèl to, kad trūksta žmogaus fiziologinių ir jo audinių termofizikinių duomenų.

2. Teorinès prielaidos ir odos virš dirbančio raumens temperatūros matavimai rodo, kad dirbantis raumuo patiria ịšilimo, nusistovejusios temperatūros ir aušimo periodus.

3. Odos temperatūros pokyčiai virš dirbančio raumens tiesiogiai susiję su dirbančio raumens apkrova, kuriai didejjant didejja ir lokali temperatūra.

4. To paties žmogaus raumens šilimo ir aušimo procesai yra tokie pat ir nepriklauso nuo fizinès apkrovos pobūdžio.

5. Lokalios odos temperatūros matavimas ir pokyčiai virš dirbančio raumens gali būti panaudoti sportininko parengtumui ịvertinti ir norint išsiaiškinti, ar sportininkui (dirbančiajam) tinka aprangos konstrukcija. 


\title{
LITERATŪRA
}

Becker, S., Potchter, O., Yaakov, Y. (2003). Calculated and observed human thermal sensation in an extremely hot and dry climate. Building and Environment, 35, 749-756.

Bennett, A. F. (1984). Thermal dependence of muscle function. American Journal of Physiology, 247 (Regulator Integrative Comp. Physiol. 16), R 217-229.

Binkhorst, R. A., Hoofd, L., Vissers, A. C. (1977). Temperature and force-velocity relationship of human muscles. Journal of Applied Physiology (Repirat. Environ. Exercise Physiol.), 42 (4), 471-475.

Čyras, P., Grinius, V., Kaminskas, A. ir kt. (2003). Profesinè sauga ir sveikata. Ergonomikos principai. Vilnius: Technika.

Fanger, P. O. (1970). Thermal Comfort. Copenhagen: Danich Technical Press.

Febbraio, M. A. (2001). Alterations in energy metabolism during exercise and heat stress. Sports Medicine, 31 (1), $47-59$.

Gagge, A. P., Saltin, B., Stolwijk, J. A. J. (1968). Muscle temperature during submaximal exercise in man. Journal of Applied Physiology, 25 (6), 679-688.

Holmer, I. (2004). Cold but comfortable? Application of comfort criteria to cold environments. Indoor Air, 14 (Suppl. 7), 27-31.

Huizenga, C., Hui, Z., Arens, E. (2001). A model of human physiology and comfort for assessing complex themal environment. Building and Environment, 36, $691-699$.

ISO 7730. (1994). Moderate thermal environments determination of the PMV and PPD indices and specification of the conditions for thermal comfort. Geneva: ISO.

Mohr, M., Krustup, P., Nybo, L., Nielsen, J. J.,
Bangsbo, J. (2004). Muscle temperature and sprint performance during soccer matches - beneficial of rewarm-up at half-time. Scandinavian Journal of Medicine and Science in Sports, 14, 156-162.

Patterson, M. J., Cotter, J. D., Taylor, N. A. S. (1998). Human sodomotor responses to heating and cooling upper-body skin surfaces: Cutaneous thermal sensitivity. Acta Physiologica Scandinavica, 163, 289-296.

Woledge, R. C. (1998). Possible effects on fatigue on muscle efficiency. Acta Physiologica Scandinavica, 162, $267-273$.

Адамчук, В. В., Варн, Т. П., Воротникова, В. В. и др. (1999). Эргономика. Под ред. проф. В. В. Адамчука. Москва: ЮНИТИ - ДАНА.

Байер, В. (1962). Биофизика. Пер. с немецкого. Москва: Изд. инностр. лит.

Золина, З. М., Измерова, Н. Ф. (1983). Руководство по физиологии труда. Москва: Медицина.

Иванов, К. П. (1990). Основы энергетики организма. Теоретические и практические аспекты. Том 1: Общая энергетика, теплообмен и терморегуляиия. Ленинград: Наука.

Кандрор, И. С. (1984). Мышечная работа - источник дополнительного теплообразования. В кн. Физиология терморегулящии. Ленинград: Наука. С. 139-180.

Кощеев, В.С. (1981). Физиология и гигиена индивидуальной защить человека от холода. Москва: Медицина.

Преображенский, В. П. (1978). Теплотехнические измерения и приборы. Москва: Енергия.

Сирвидас, А., Юшка, В. (1973). Измерение температуры растений в микро-климатических и физиологических исследованиях. Каунас.

\section{REGULARITIES OF SKIN TEMPERATURE CHANGES OVER WORKING MUSCLE}

\section{Povilas Algimantas Sirvydas¹, Albertas Skurvydas, Jūratė Nadzeikiene் ${ }^{1}$, Saulė Sipavičienė} Lithuanian University of Agriculture ${ }^{1}$, Lithuanian Academy of Physical Education, Kaunas, Lithuania

\begin{abstract}
All sorts of energy, including biological and mechanical energy, finally deteriorate into heat. The heat exudes during physical strain impacting human energy balance and displaying in local temperature increase. The local temperature increase in working muscles conforms to the low level of thermodynamics.

There are analyzed changes of skin temperature over working muscle in the article. On the basis of heat balance skin temperature change alteration dependence on interdependent internal and external factors substantiated, skin temperature change in time-span differential equation was deduced. Accomplished measurements of skin temperature over working muscle sustained the theoretic postulate that working muscle sustains heating, steady temperature and cooling periods. Investigations of skin temperature over working muscle and changes of that temperature can be applied for the assessment of a sportsman's preparedness and substantiation of a sportsman's (worker's) clothing construction.
\end{abstract}

Keywords: heat balance, local temperature, muscle.

Gauta 2004 m. lapkričio 2 d.

Received on November 2, 2004

Priimta $2005 \mathrm{~m}$. vasario $2 \mathrm{~d}$.

Accepted on February 2, 2005
Povilas Algimantas Sirvydas

Lietuvos žemès ūkio universitetas

(Lithuanian University of Agriculture)

Universiteto g. 15, Akademija, Kauno r. LT-53356

Lietuva (Lithuania)

Tel +370 37752317

E-mailsirvydas@tech.lzuu.lt 